\title{
Creatures, the Academic Lawyer and a Socio-Legal Approach: Introducing Animal Law into the Legal Education Curriculum
}

\author{
Simon Brooman ${ }^{1}$
}

Published online: 21 September 2017

(C) The Author(s) 2017. This article is an open access publication

\begin{abstract}
Legal education has witnessed a significant rise in the number of Animal Law courses since 1989, especially in the United States where 164 universities have offered the subject. This article discusses the world-wide growth in provision in the context of a failure to match this impetus in the United Kingdom. It addresses how the continuing rise in the profile of legal issues relating to animals such as the failure to control the disappearance of species, links between poaching and international terrorism and the welfare of 56 billion animals slaughtered for meat worldwide have been largely ignored by the UK legal academy. Possible reasons for this are postulated including a professional realignment of UK legal education. An approach to Animal Law grounded in the methodology of socio-legal studies is discussed. It is suggested that Animal Law provides an opportunity for the UK legal academy to contribute its particular skills to the development of this new area of legal education and research. It would help move UK legal education towards a greater recognition and provision regarding the interaction of sustainable human activities, animals and the law.
\end{abstract}

Keywords Animal Law · Socio-legal studies · Sustainability · Legal education - Animal law courses in the UK

Position Paper: The Editors invite comments upon the issues raised by the author, a sample of which may be published in a future edition of this journal.

Simon Brooman

S.D.Brooman@ljmu.ac.uk

1 School of Law, Liverpool John Moores University, Redmonds Building, Brownlow Hill, Liverpool L3 5UG, UK 


\section{Introduction and Context}

The United Kingdom has often been a pioneer in the development of laws to protect animals. For example, the Brambell Report of 1965 lead to much stronger legislative control and is widely recognised as having set the international benchmark for the treatment of farm animals. ${ }^{1}$ It is the birthplace of organisations such as the Royal Society for the Prevention of Cruelty to Animals ${ }^{2}$ and a selfproclaimed 'lover of animals'. However, does this apparent appreciation of animals extend to the legal academy?

Many philosophers have discussed the differences between the humans and nonhuman animals as a way of explaining what it is to be human. Plato (427-347 BC) and Aristotle (384-322 BC) compared humans to animals in order to explain the basis of legal systems. ${ }^{3}$ The 1970 s and 1980s witnessed a significant increase in the philosophical attention given to humans' interaction with other species. Writers such as Peter Singer, Tom Regan and Richard Ryder ensured that the nature of this relationship became a key feature of philosophical education and supported political decision making in developing laws relating to animals. ${ }^{4}$ As a result, it was philosophers from the academy, not lawyers, who advised the government on its changes to the regulation of animal use in experimentation in $1986 .{ }^{5}$ We see this more recently in 2017 when the European Union (EU) Energy and Environment Parliamentary Sub-Committee received evidence from 14 academic and interest group representatives in a round-table discussion on the legal implications for farm animal welfare following Brexit. ${ }^{6}$ None of these was a practicing lawyer, legal academic or EU law expert. ${ }^{7}$

Amongst academic lawyers, it is only recently (since around 2005) that Animal Law has attracted attention as a distinctive area of study. A study by Professor Peter Sankoff in 2006-2007 suggested that the UK matched the United States in the early growth of university provision of Animal Law in the period 1989-1999. ${ }^{8}$ By 2010, the US had witnessed the emergence of more than 70 courses. By 2014, this figure had risen to 148 universities and the UK stood still. ${ }^{9}$ In 2008, the American

\footnotetext{
1 "Report of the Technical Committee to enquire into the welfare of animals kept under intensive livestock husbandry systems." Chairman: Professor F. W. Rogers Brambell. Cmnd. 2836, December 3 1965. Her Majesty"s Stationery Office, London; See also "Farm Animal Welfare: Past Present and Future" (2009) Farm Animal Welfare Council http://www.fao.org/fileadmin/user_upload/animalwelfare/ ppf-report091012.pdf. Accessed 12th April 2017.

2 S. Brooman and D. Legge, Law Relating to Animals (London, Cavendish Publishing, 1997) p. 43.

3 id, p. 6.

${ }^{4}$ S. Brooman and D. Legge, supra n. 2, pp. 1-29.

5 Animals (Scientific Procedures) Act 1986. See Brooman and Legge, supra, n. 2, p. 129.

6 See record of discussions at https://www.parliament.uk/business/committees/committees-a-z/lords-select/ eu-energy-environment-subcommittee/news-parliament-2015/brexit-farm-animal-welfare-roundtable/.

7 Although Peter Stevenson is a qualified lawyer working for Compassion in World Farming.

8 P. Sankoff, "Charting the Growth of Animal Law in Education" (2008) 4 J. of Animal Law 105, p. 121.

9 R. DeMeo and G. Morton, “Animal Law in Florida: Here and Now” (2014) 88: 9 The Florida Bar Journal 8 .
} 
Association of Law Schools approved the creation of an Animal Law section to help develop a coherent methodology and dialogue for this diverse area of study. ${ }^{10}$ Of Australia's 27 Law schools, 12 offered a course in Animal Law by 2013. ${ }^{11}$ Brazil also has a significant number of Animal Law courses as do many other countries. ${ }^{12}$

A comprehensive study of LLB courses was undertaken (August/September 2017) in order to ascertain an up-to-date figure for Animal Law course/modules in the UK. The on-line details of every single-honours LLB course in the UK listed in unistats.com was examined, particularly in relation to option module provision in years two and three:

Number of United Kingdom LLB courses investigated for Animal Law or similar provision: 109

Number of Animal Law or Animal Welfare modules being delivered in 2017:

Five. These are the University of Aberdeen (Animal Welfare Law), University

of Essex (Animal Welfare and Wildlife Law), University of Northumbria (Animal Law), Liverpool John Moores University (Animal Welfare Law) and the University of Lincoln (Animal Law and Ethics).

In addition, the on-line detail of Environmental Law modules offered on those 109 UK LLBs (22) was examined to identify whether there is mention of the word 'animal' or 'animal law'. Only one LLB Environmental Law option module offered by the Queen Mary University of London has any content related to Animal Law (Whaling). As for the others, it is likely that any Animal Law content in those modules is very limited or absent. In addition, the LLB offered by the School of Oriental Studies in London offers a Law and Nature module that mentions areas relating to endangered species. The University of Surrey LLB offers an Environmental Law in Action module which mentions the protection of wildlife as one of its areas of study.

It is concluded that Animal Law provision in UK Law Schools has remained static for a number of years. This appears to be a problem common to a number of applied law subjects offered which are on the fringes of LLB provision and heavily influenced by socio-legal studies. These include Cultural Legal Studies, Social Welfare Law, Law and the Human Body, Law, Literature and Film, Gender and the Law, Religion, Law and Society, Terrorism and the Law, Women and Law and many others. None of these has managed to gain a foothold in more than a handful of universities although specific numbers were not gathered in this study-the only exception is Environmental Law which appears on 24 of the 109 LLBs offered in the UK. It appears that Animal Law is subject to the same limiting effects experienced by many other applied socio-legal subjects. They are taught by 'enthusiasts' and their modules tend to move between universities with the staff who

\footnotetext{
${ }^{10}$ M. Senatori and P. Frasch, "The Future of Animal Law: Moving Beyond Preaching to the Choir" (2010) 60: 2 J. of Legal Education 209, p. 211.

11 N. James and R. James, "Teaching Animal Law Best Practices", University of Tasmania, Australia, Conference on Animal Law, January 2013, see http://www.utas.edu.au/law/research/utas-animal-lawconference/schedule. Accessed 14 April 2017.

12 Tagore Trajano de Almeida Silva, "Origins and Development of Teaching Animal Law in Brazil" (2014) 31: 2 Pace Environmental Law Review 501.
} 
teach them. This contrasts with the success of Animal Law in other countries where academics consider it to have a particular moral and philosophical importance.

Some writers discuss laws relating to animals in a manner that places Animal Law as a sub-category of Environmental Law. ${ }^{13}$ However, this article takes the epistemological position that, although it is related to Environmental Law, Animal Law is a distinct area which should be considered as a 'sister' subject, not 'subcategory' of Environmental Law. Although animals exist within the environment, animal sentience gives rise to a new set of parameters deserving of consideration in addition to the protection of habitats. ${ }^{14}$ There is no evidence to support the contention that animal sentience and the potential for suffering can be addressed by considering them only as part of the environment. ${ }^{15}$ On the contrary, there are many contributions suggesting the opposite. ${ }^{16}$

This article discusses what Animal Law can add to legal education and what motivated the creation of one particular Animal Law course at undergraduate level. It details the socio-legal approach that was adopted as opposed to the doctrinal approach that seemed to be favoured in existing textbooks. It should be noted that there are other discussions taking place in the literature such as the link between Animal Law and feminist legal studies_-but space does not allow for all of these to be unpicked here. The reader should be aware that a number of conversations are taking place to address the theoretical positioning of Animal Law. ${ }^{17}$

The intention here is to make the case as to why law teachers might design and deliver a curriculum in Animal Law and how they might select an appropriate methodology to do so. The extant factors hampering the development of Animal Law in the UK need mentioning as the impact of the Legal Education Training Review (LETR) is yet to play itself out at the time of writing (September 2017). The full implications for legal education and socio-legal studies are yet to be realised. Anecdotal evidence suggests that some universities are placing practice-based subjects within the traditional law degree. The implications for applied legal studies option modules may be serious as requirements of the new Solicitors Qualifying Exam (SQE) emerge from the LETR. However, for the purposes of this article the assumption is made that socio-legal studies are not about to become extinct and the law degree will retain a purpose and identity other than to service the requirements of the solicitors' profession.

The focus of this paper is whether a philosophical, scientific and historical context to the study of Animal Law make this an interesting area to introduce into more law schools. The answer emphasises an Animal Law curriculum grounded in socio-legal methodology to help encourage deep learning in this growing area of study. A limitation of this paper is that it does not provide details regarding the research opportunities and external links that could be exploited by staff. That may become apparent to the reader and will hopefully emerge in future Animal Law literature.

13 J. McEldowney and S. Mceldowney, "Science and Environmental Law: Collaboration across the Double Helix" (2011) 13: 3 Env L Rev 169, p. 187.

14 S. Brooman and D. Legge, supra n. 2, p. 23.

15 S. Brooman and D. Legge, supra n. 2, pp. 31-69.

16 G. Francione, Rain Without Thunder: The Ideology of the Animal Rights Movement (Philadelphia: Temple University Press, 1996) pp. 127-34.

17 S. Armstrong and R. Boltzer, The Animal Ethics Reader (London: Routledge, 2008). 


\section{The International Momentum of Animal Law}

The limited number of Animal Law courses in the UK may be due to a similar effect encountered in the development of Environmental Law. ${ }^{18}$ This area is suitable to compare with Animal Law because of the connections between the two subjects. Both have fringe status in UK law schools as well as connections through their exploration of the relationship between law and the natural world. Environmental Law is a useful subject with which to compare Animal Law because of its synchronous green credentials.

Law relating to animals appears in mainstream law subjects that form part of a traditional package of legal study. For example, the status of animals as property sees them largely dealt with as chattels, an approach which was passed down from the Ancient Greeks, via the Romans and religious teaching in the Middle Ages. ${ }^{19}$ However, these connections are relatively minor in light of the continuing development of areas of international and national interest to the researcher and student of Animal Law, as these examples show:

- More than 115.5 Million animals used world-wide in experimentation ${ }^{20}$

- Growing evidence of the use of trade in endangered species to fund terrorist activities $^{21}$

- 56 billion animals slaughtered for food across the globe each year ${ }^{22}$

- National-level conflicts between wildlife protection and human activities e.g. badger-culling ${ }^{23}$

- Discussions to re-start whaling at the International Whaling Commission ${ }^{24}$

- Growing scientific evidence of animal suffering e.g. in religious slaughter ${ }^{25}$

- Establishing links between animal abuse and child abuse ${ }^{26}$

- The conflict between international free trade and animal welfare ${ }^{27}$

${ }^{18}$ G. Little, "Developing environmental law scholarship: going beyond the legal space" (2016) 36: 1 Legal Stud 48.

${ }^{19}$ S. Brooman and D Legge, supra n. 2, pp. 50-55.

${ }^{20}$ Animal Studies Repository, Humane Society of the United States, http://animalstudiesrepository.org/ acwp_lab/14/. Accessed 26th January 2017.

${ }^{21}$ L. Douglas and K. Alie, "High-value natural resources: linking wildlife conservation to international conflict, insecurity, and development" (2014) 171 Biological Conservation, 270.

${ }^{22}$ Worldwatch Institute, 2016 see http://www.worldwatch.org/node/5443. Accessed 8th March 2017.

${ }^{23}$ H. Jenkins, R, Woodroffe and C, Donnelly, "The Duration of the Effects of Repeated Widespread Badger Culling on Cattle Tuberculosis Following the Cessation of Culling" (2010) 5(2) PLOSone. Available online at http://journals.plos.org/plosone/article?id=10.1371/journal.pone.0009090.

${ }^{24}$ J. Smith "Evolving to Conservation?: The International Court"s Decision in the Australia/Japan Whaling Case" (2014) 45(4) Ocean Development and International Law, 301, pp. 303-305.

${ }^{25}$ S. Brooman "In Search of the Missing Ingredient: Religious Slaughter, Incremental Failure and the Quest for the Right to Know" (2016) 6 J. of Animal Ethics 153.

${ }^{26}$ A. Linzey (ed) The Link Between Animal Abuse and Human Violence (Sussex: Sussex Academic Press, 2009).

${ }^{27}$ S. Brooman and D. Legge "Animal Welfare vs Free Trade-Free Trade Wins: An examination of the Animal Welfare Implications of R v MAFF ex p Compassion in World Farming (1998)" (2000) 9 Animal Welfare 81 . 
The United States has seen the emergence of partnerships between the profession and academia through the Animal Legal Defense Fund which advocates for the enhanced protection of animals. They attempted, unsuccessfully, to secure personhood status for chimpanzees but have other successes. ${ }^{28}$ The connection between the US legal academy and the profession is developing the potential to influence the development of law. A similar partnership is emerging in the UK through the Association of Lawyers for Animal Welfare (ALAW).

\section{The Socio-Legal Context of Animal Law}

The value of a socio-legal approach to law is widely recognised by a wealth of published evidence, degree programmes and professorial appointments. It is said to have originated in the United States in the 1920s and then picked up in the United Kingdom in the 1960s. ${ }^{29}$ Scholars utilising socio-legal methodology analyse law in the context of wider societal issues, perspectives and concerns. ${ }^{30}$ Socio-legal studies now has a recognised place in legal scholarship besides doctrinal research ${ }^{31}$ and only the boundary of socio-legal research is contested. Dermott Feenan explains how determining a precise definition of the 'socio in socio-legal studies' has been illusive for scholars. However, he recognises that one of the chief aims of socio-legal studies is to improve the basis of legal change which seems appropriate for Animal Law:

The aspiration for social improvements underpinned by legal reform is constant where humans dream of a better future. We should not limit the scope of our imagination to that which is already known, but allow for that which is also possible. ${ }^{32}$

In the academy, most legal scholars now recognise or refer to themselves as 'sociolegal scholars.' As Kim Economidies notes:

Legal Academics may not overtly classify their scholarship as sociolegal...yet, on the other hand, most eschew esoteric theory or pure doctrinal analysis... [and] may expose law students to a pragmatic empiricism that boils down to asking two connected socio-legal questions: 'what is the law?' and 'does it work?'33

\footnotetext{
${ }^{28}$ Animal Legal Defense Fund see http://aldf.org/press-room/. Accessed 12th April 2017.

${ }^{29}$ M. Alder and J. Simon, "Stepwise Progression: The Past, Present and Possible Future of Empiracal Research on Law in the United States and the United Kingdom" (2014) 41: 2 J. of Law and Society 173, at p. 176.

${ }^{30}$ H. Arthurs and A. Bunting, "Socio-legal Scholarship in Canada: A review of the Field" (2014) 41: 4 J. of Law and Society 487, p. 487.

${ }^{31}$ F. Cownie, F, Legal Academics: Culture and Identities (Oxford: Hart Publishing, 2004); A. Carline, H. Baker, (2008) "Socio-Legal Studies in Liverpool Law Schools Introduction" 29: 2 Liverpool Law Review 117.

${ }^{32}$ D. Feenan, Exploring the "Socio" of Socio-Legal Studies (Basingstoke: Palgrave MacMillan, 2013) 15.

${ }^{33}$ K. Economides, "Socio-legal studies in Aotearoa/New Zealand" (2014) 41: 2 J. of Law and Society 257, p. 259
} 
Many socio-legal scholars view law through the lens of other disciplines which may include, for example, history, economics, psychology, and 'even geography'. 34 The advantage of such an approach is that it avoids 'decontextualisation'-law cannot be understood unless its impact in wider society and its effect on individuals is understood. ${ }^{35}$ Guth and Ashford suggest that:

'Socio-legal studies' means different things to different scholars and is probably best understood as crossing the boundaries of law in context, empirical work, social science methodologies and non-doctrinal work more broadly. ${ }^{36}$

Therefore, applying and describing socio-legal methodology encompasses not only a description of the method of data analysis or approach to discussing knowledge but also the reasoning behind the decision to employ that method. The approach to Animal Law discussed here is under-pinned by this socio-legal methodology. The education research-based thinking that underpinned the design of a new Animal Law curriculum was that it would stimulate students' interest in the subject, introduce a method for critical analysis and provide a curriculum for deep learning. Higher education research literature recognises that wider context often provides a thought provoking context to stimulate student learning. ${ }^{37}$

\section{A Socio-Legal Curriculum for Animal Law}

It is important to explain the methodology of an Animal Law curriculum to allow scholars to examine whether the approach is logical and justified. ${ }^{38}$ Fisher et al. suggest that a failure to do this systematically in the case of Environmental Law was one of the reasons that delayed its development and recognition, and created confusion and reluctance to engage with the new subject. ${ }^{39}$ They also suggest that a clear methodology helps to put a new area of study on a firmer footing. ${ }^{40}$

Four interlinked methodological considerations were addressed to design a new Animal Law curriculum at undergraduate level:

\footnotetext{
34 A. Boon, "Integrating Socio-Legal Studies into the Law Curriculum" (2012) edited by Caroline Hunter, New York: Palgrave Macmillan, (2012) 39: 4 J. of Law and Society 616.

35 L. Charlesworth, "On Historical Contextualisation: Some Critical Socio-Legal Reflections" (2007) 1: 1 Crimes and Misdemeanours 1.

36 J. Guth and C. Ashford, "The Legal Education and Training Review: regulating socio-legal and liberal education?" (2014) 48: 1 The Law Teacher 5, p. 11.

37 M. Healey, "Developing the scholarship of Teaching in Higher education: a discipline-based approach" (2000) 19:2 Higher Education Research and Development 169; A. Brew "Transforming academic practice through scholarship" 2010 15: 2 International Journal for Academic Development 105: E. Hagstrom and O. Lindberg, "Three theses on teaching and learning in higher education" (2013) 18: 2 Teaching in Higher Education 119; M. Tight, "Discipline and theory in higher education research" (2014) 29: 1 Research Papers in Education 93.

38 E. Fisher, B. Lange, E. Scotford and C Carlarne, "Maturity and Methodology: Starting a Debate about Environmental Law Scholarship" (2009) 21(2) J. of Environmental Law 213.

39 Fisher et al., supra n. 37, pp. 226-7.

${ }^{40}$ Fisher et al, supra n. 37, p. 244.
} 
1. Should the subject be located in traditional doctrinal or external socio-legal methodology?

2. How, and where, should Animal Law research be conducted?

3. Which external discipline(s) might offer coherent evidence-based approach suitable for Animal Law?

4. What would be the best way to utilize knowledge from these disciplines to create an interesting and informative curriculum and so encourage deep learning?

An answer to the first question emerged during the first year of teaching Animal Law. Doctrinal methods failed to address a significant question raised by philosophers in the 1970s and 1980s-is the law fit for purpose? An approach, which could broadly be termed as socio-legal-i.e. looking for an external critique and appreciation of the contextual impact of laws relating to animals - appeared to be more desirable because of the limited reach of legal scholarship in the area. The rationale matched that of Matyas Bodig who notes:

'[I]nterdisciplinary engagement is sometimes necessary for legal scholars because some concepts and ideas built into the doctrinal structures of law cannot be made fully intelligible by way of pure normative legal analysis. ${ }^{41}$

To answer the second question as to how to research the area, the empirical methodology applied was similar to that recognised as effective in other disciplines by Tranfield, Denyer and Smart. $^{42}$ The best legal, historical, scientific and philosophical contributions were selected following a systematic review of all available sources. This process of research took place over 4 years using over fourhundred sources.

The third question regarding appropriate discipline areas was answered by a wealth of philosophical and scientific discussion in the areas of animal sentience, ability to suffer pain and basic welfare standards for different species based on their natural behaviour. These two disciplines also appeared to answer the fourth question in that they could provide an interesting context for students. They would guide students' research in the area, involve a deeper appreciation of the law and develop a method of critical reasoning in Animal Law embedded in the "moral framework of human discourse. ${ }^{43}$ Another significant theme was the dominant issue of historical context, so adding a third discipline upon which to design this overall approach. The addition of an historical approach helps students to gain an appreciation of the connection between legal, historical, philosophical and scientific reasoning. It allows a critique of extant law as a reflection of the prevailing philosophical thinking and scientific knowledge at the time it was introduced. Concerns raised in

\footnotetext{
${ }^{41}$ M. Bodig, "Legal Doctrinal Scholarship and Interdisciplinary Engagement" (2015) 2 Erasmus Law Review 42, p. 42.

42 D. Tranfield, D Denyer and P. Smart, "Towards a Methodology for Developing Evidence-Informed Management Knowledge by Means of Systematic Review" (2003) 14 British Journal of Management 207.

43 J. Shaw "Reimagining Humanities: Socio-Legal Scholarship in the Age of Disenchantment" in D Feenan (ed) What is Socio-Legal Studies? (London: Palgrave MacMillan, 2013) p. 112.
} 
the modern day often have a contentious 'mirror history' which can inform an approach to reform. For example, a discussion of the introduction of the first animal protection legislation in the UK in 1822 to prevent bull-baiting at fairs and wakes was contested by those unwilling to lose a tradition stretching back some six hundred years. ${ }^{44}$ Foxhunting continues to attract deeply entrenched views and there are calls for the rights of landowners and tradition, stretching back to William the Conqueror, to be given precedence over welfare concerns. Critical awareness of the historical context stimulates student interest when discussing these historical connections.

The student researcher is exposed to all sides of the philosophical debate to avoid the criticism of 'blinkered vision,' as has been suggested was the case in teaching Environmental Law. ${ }^{45}$ However, as Hillyard observes of those involved in sociolegal scholarship, I am influenced by 'a vision of a just society which is informed by moral indignation.' I freely admit that my personal position can sometimes be difficult or impossible to conceal. ${ }^{46}$ Conversely, this translates positively for students who often comment on my passion for the subject in feedback.

This approach to studying Animal Law encourages students to ask the following questions: How has the law arrived at its current position? What scientific evidence (e.g. of animal suffering/scientific validity of research) is available in the area in question? How does this impact on the philosophical and ethical discussions in the area? And, what are implications for reform? This has influenced curriculum design elsewhere as shown by a survey of learning objectives on Animal Law courses in Australia. $^{47}$

The discussion above attempts to add academic and methodological rigor to Animal Law and clarity to the curriculum. ${ }^{48}$ Other approaches are possible in building a new subject area. For example, it is easy to appreciate the value of doctrinal research regarding the ability of the Common Agricultural Policy to deliver on aspects of animal welfare, ${ }^{49}$ or the use of the precautionary principle of EU Law to protect animals used in experimentation. ${ }^{50}$ Articles combining a doctrinal analysis and a socio-legal approach are becoming much more common where it is very difficult to separate the discipline of law from moral concern, such as the continuing plight of chickens in United States farming, ${ }^{51}$ and whaling. ${ }^{52}$ However, I suggest that a socio-legal approach is vital in order to appreciate the

\footnotetext{
44 An Act to Prevent the Cruel and Improper Treatment of Cattle. [22 July 1822]. See S. Brooman and D Legge, supra n. 2, pp. 40-43.

45 Fisher et al, supra n. 37, p. 222.

46 P. Hillyard "Invoking Indignation; Reflections on Future Directions of Socio-Legal Studies" (2002) 29: 4 J. of Law and Society 645, p. 656.

47 N. James and R. James, supra n. 10.

48 G. Little, supra n. 18, p. 26.

49 D. Ryland, “Animal Welfare in the Common Agricultural Policy: Wherefore art thou?" (2015) 17: 1 Environmental Law Review 22.

50 J. McEldowney and S. McEldowney, supra n. 13, p. 187.

51 V. Watnick, "The business and ethics of laying hens: California"s ground-breaking law goes into effect on animal confinement" (2016) 43: 1 Boston College Environmental Affairs Law Review 45.

52 J. Smith, supra n. 24 , p. 301.
} 
importance of the subject as a vehicle for discussions around morality, human values, environmental degradation, sustainability, animal welfare, cruelty and the protection of endangered species.

The use of external disciplines to develop a new subject area need not be a oneway street-legal scholars have much to contribute to research in this area. ${ }^{53}$ It has been noted by environmental lawyers that their intention in using the tools of other disciplines was not to entirely hand over the issue to scientific experts but to work with them to improve the scope and facility of law-making a contribution to subject/discipline development is vital. ${ }^{54}$

\section{Why Has Animal Law Failed to Develop Amongst Legal Education Providers in the UK?}

Nicole Graham notes a reluctance of legal scholars to engage with knowledge beyond the confines of law in relation to the environment and sustainability. ${ }^{55}$ It has been suggested that there is a world-wide challenge for legal education to show 'more fluidity in the boundaries between law and other professional disciplines', and that 'exposing lawyers to the mind-sets and assumptions of other disciplines can be a powerful experience. ${ }^{56}$ The emergence of Wild Law has also encountered the inertia of current legal norms. Helena Howe notes: 'Until we change our thought processes-our jurisprudence-we cannot change the way we regulate our interactions with the natural world'. 57

It seems that legal education sometimes struggles to look beyond its own boundaries, particularly in the areas associated with the green agenda. The lack of momentum in the development of Animal Law has affected the development of other 'green' issues in legal education. Jamie Murray notes that ecological approaches to law emerged in the 1970s, but the central call for the need to link law and ecology has yet to fully materialise despite gathering momentum more recently. ${ }^{58}$ 'Green' law subjects have failed to gain a critical mass necessary to make a meaningful contribution to issues of sustainability. For Animal Law this means few contributions by legal scholars in vital areas such as the disappearance of species or exploring the relationship boundaries between science and law in light of new knowledge about animal sentience. ${ }^{59}$

\footnotetext{
53 Fisher et al, supra n. 37, p. 248.

54 N. Turget "The Influence of Ecology on Environmental Law: Challenges to the Concept of Traditional Law" (2008) 10 Env L Rev 112, p. 124.

55 N. Graham, "This is not a thing: land, sustainability and legal education" (2014) 26 J Environmental Law 395.

56 P. Baron and L. Corbin, "Thinking like a lawyer/acting like a professional: communities of practice as a means of challenging orthodox legal education" (2012) 46: 2 The Law Teacher 100, pp. 116-117.

57 H. Howe "Making Wild Law Work-The Role of "Connection with Nature" and Education in developing Ecocentric Property Law” (2017) 29 J Environmental Law 19, p. 24.

58 J. Murray, "Earth Jurisprudence, Wild Law, emergent Law: The Emerging Field of Ecology and Law-Part 1”, (2014) 35 Liverpool Law Review 215, p 217.

59 G. Little, supra n 15, p. 2.
} 
The spectre of the long-running Legal Education Training Review (LETR) highlights another factor that has delayed Animal Law or other 'green' socio-legal subjects gaining a foothold in legal education provision in the UK. ${ }^{60}$ The SQE has cast a cloud on the immediate future of legal education and dominates the recent past. The LETR embraces discussion amongst professionals and educators as to the form and function of legal education provision in England and Wales. A significant component is the role of undergraduate education and its fitness to provide students with skills to enter the legal professions. UK law schools have been immersed in 'conversations' about providing skills to match these purposes-not the boundaries of socio-legal scholarship. It is conjectured here that that these discussions have severely curtailed the development of socio-legal approaches to legal education, including Animal Law. The legal academy has been caught up in defence of its relevance to the future of legal training-notions of skills, job-readiness, employability and academic survival are not the natural precursors to discussion of the relevance of legal education to sustainability, animal welfare, wild law or the loss of species.

Guth and Ashford (2014) discuss the risks for socio-legal education enmeshed in the LETR, which may remove from UK law degrees a significant element of the development of analytical skills and critical thought and external awareness:

Students will therefore be robbed of the opportunity to engage with rich sociolegal writing on a wide variety of topics and will not be pushed to explore the variety of angles and stories which are influenced by law and indeed influence law. This would be a shame for the future of socio-legal studies but would be a disaster for liberal law degrees. ${ }^{61}$

Hopefully, the new SQE will not signal the end of the traditional law degree or socio-liberal aspects of it. The UK law degree currently serves the dual purpose of providing a broad liberal arts education and advances the student towards the professions. Those working in socio-legal studies see the advantages of educating law students in the light of external context. ${ }^{62}$ Discussion about Animal Law adds to conversations about who 'owns' the law degree? The profession, the academy or both?

\section{Why Should You Introduce Animal Law to Your University?}

Despite apparent uncertainties in the direction of legal education, you may be one of those in the UK legal education academy who recognises the value of Animal Law. The moral and philosophical elements of studying such an emotive subject make this an attractive area for many students and it is odd that the country of animal

\footnotetext{
60 "Setting Standards: The Future of Legal Services Education and Training Regulation in England and Wales." (2013) The Final Report of the Legal Education and Training Review independent research team. See http://www.letr.org.uk/the-report/. Accessed 26th February 2017.

61 J. Guth and C. Ashford, supra n. 35, p. 13.

62 J. Guth and C. Ashford, supra n. 35, p. 13.
} 
lovers has failed to match student demand which is satisfied in other countries. There is no evidence that the legal academy is less predisposed to the plight of animals that the rest of the UK population but there is a lingering suspicion from the socio-legal v doctrine debate that doctrinal English law teachers can be harsh judges of 'fringe subjects' such as Environmental Law and Animal Law.

The reason why you might decide to design an Animal Law course is unlikely to be an overwhelming doctrinal case for its inclusion. It is more likely to be fuelled by Hillyard's 'sense of indignation' as an individual reacts to injustice in the treatment of animals. ${ }^{63}$ I suggest that the greatest influence for joining the development of Animal Law is an appreciation and understanding of why it matters - the interaction of moral values and law lies at the heart of Animal Law. It piques the interest of many students, joins contemporary public debate, addresses key questions about what it is to be human and brings the study of law closer to issues of sustainability and the future preservation of species, including homo sapiens. How many law subjects touch on human cruelty or the future of the planet?

Kristin Stilt of Harvard Law School expresses her motivation for teaching Animal Law: 'We know how law doesn't work for animals, but we have no clear idea yet about how it should. ${ }^{, 64}$ The boundaries of this subject are in the early stages of development-part of the reasoning to introduce Animal Law into the legal education syllabus revolves around its newness. Animal Law brings the possibilities of original research and connections with politics and environmental awareness. As legal academics, we often look beyond the needs of business to seek the wider context and impact of law. However, as well as listening to our 'inner voices', there may be less individually-located guidance which supports the introduction of Animal Law more widely in the UK legal academy.

Conversely to its focus on the needs of the profession and the gloomy predictions alluded to above, the LETR may provide part of the reasoning for the introduction of Animal Law and other more socio-politically related courses into undergraduate or post-graduate, legal education. However, the reference is hardly the clearest signal of the need to enhance provision with courses such as Animal Law. The Report recommends that:

The learning outcomes at initial stages of LSET [Legal Skills and Education Training] should include reference (as appropriate to the individual practitioner's role) to an understanding of the relationship between morality and law.' 65

The proposed United Kingdom National Law Subject Benchmark Statement specifically embraces the need for legal education to develop a broad range of skills

\footnotetext{
63 P. Hillyard, supra n. 52, p. 656.

64 C. Feinburg “Are Animals Things?” (2016) Harvard Magazine March-April 40, p. 42. http://harvardmagazine.com/2016/03/are-animals-things. Accessed 1st March 2017.

65 LETR, supra n. 74, p. 287.
} 
in law students. ${ }^{66}$ It is a clear statement by a regulator that there needs to be a focus on aspects of knowledge beyond the traditional confines of legal education in the developing the 'qualities of mind' of the law student:

- awareness of principles and values of law and justice, and of ethics;

- knowledge and understanding of theories, concepts, values, principles and rules of public and private laws within an institutional, social, national and global context. $^{67}$

There is little guidance as to what is meant by some of these phrases but they can clearly be read as recommending the desire to develop students' sense of morality and issues around the sustainability of human activities, including those raised by Animal Law.

The concept of 'sustainability' stresses the need for future human activities to be conducted to preserve the balance of the environment. Amongst legal educators it has been described as 'among the most important ideas to come out of the twentieth century. ${ }^{68}$ Legal education in the UK seems to have overlooked, almost entirely, the Decade of Education for Sustainable Development (2005-2014). ${ }^{69}$

The introduction of Animal Law might help address what Nicole Graham suggests is inertia inherent in the 'institution of law' that largely ignores the concept of public environmental responsibilities. In discussing Land Law Graham suggests that:

Despite significant pedagogical and philosophical differences between conventional and critical approaches to legal education, and despite very different ideologies of law itself, the thread of anthropocentricism is common to most in that land is presented as the 'thing' of property relations between 'persons'. It is time to acknowledge that land is not a 'thing' and that the occasion for rethinking law's categories has arrived-the adverse environmental effects of institutionalised anthropocentricism are evident. ${ }^{70}$

Vito de Lucia also suggests that legal education may need to look to developments in knowledge outside law, and re-align with issues of environmental sustainability:

\footnotetext{
66 Quality Assurance Agency "Subject Benchmark Statement Law” (Gloucester: QAA, 2015) See http:// www.qaa.ac.uk/publications/information-and-guidance/publication?PubID=2966\#.VtAxA8ZFDdY. Accessed 26th February 2017.

67 QAA, supra n. 63, p. 7.

68 J. Dernbach, "The essential and growing role of legal education in achieving sustainability" (2011) 60:3 J. of Legal Education 489, p. 490.

69 UNESCO Resolution 57/254 on UN Decade of Education for Sustainable Development. 57th Session, 20th Dec 2002.

70 N. Graham, supra n. 57, p. 422.
} 
[T] he role of law, and of legal scholarship, may be significant, particularly if seen from the point of view of an urgent need to re-orient law in an ecological direction. Law is in fact both product and producer of a particular worldview. $^{71}$

Animal Law does not correct this lacuna in legal education. Definitions of sustainability go beyond that which is rectified by Animal Law alone and endeavours to develop Wild Law are strongly related to these discussions. However, it might go at least part of the way in answering the call for higher education to focus on curricular development aspects of sustainability rather than, for example, improving the impact of campus design. ${ }^{72}$

Animal Law stimulates discussions around the connections between human activities and their effect on animals and the environment. ${ }^{73}$ Law schools offering law courses addressing issues of sustainability have begun to appear across the US, including post-graduate and $\mathrm{PhD}$ study. ${ }^{74}$ This has not been the case in the UKAnimal Law could part form part of provision to address UNESCO's call to introduce students to aspects of sustainability in their education.

In addition, the introduction of Animal Law courses in UK universities could give rise to the potential of more direct involvement of the academy and law students in developing an advocacy link along the lines of the example set by the Animal Legal Defense Fund in the US. This aligns with calls for legal scholarship to be guided by the objective of moving and developing the direction of law as it is applied in practice. ${ }^{75}$ It would enable members of the UK legal academy to influence the development of a methodology of Animal Law at home and in other countries which currently look to the US for influence and guidance. ${ }^{76}$

\section{Conclusion}

Animal Law is in the early stages of its development in the UK despite being part of the curriculum in some universities since the early 1990s. It lacks the critical mass of academic involvement in the United States or Australia having moved through perceptions of ridicule, misunderstanding, begrudged acceptance and then recognition from other UK law academics. Animal Law is a subject fit for the future of legal education as it asks for members of the academy to develop students ready for

\footnotetext{
71 V. De Lucia, "Competing Narratives and Complex Genealogies: The Ecosystem Approach in International Environmental Law" (2014) 27: 1 J. of Environmental Law 91, p. 117.

72 B. Christie, K. Miller, R. Cooke and J. White, "Environmental sustainability in higher education: how do academics teach?" (2012) 19: 3 Environmental Education Research 385, p. 386.

73 J. Holder, "Identifying Points of Contact and Encouragement Between Legal and Environmental Education” (2013) 40: 4 J. of Law and Society 541, at p. 547.

74 J. Dernbach, supra, n. 72, at p. 504.

75 D. Hricik and V. Salzmann, "Why there should be fewer articles like this one: law professors should write for legal decision-makers and less for themselves" (2005) 38 Suffolk University Law Review 761, at p. 765 .

76 T. de Almeida Silva, supra n. 11, p. 507.
} 
the real world and its interdisciplinary nature brings with it exposure to new methodologies and approaches to law. 'Green issues' have been largely ignored by the legal academy as witnessed by the experience of Environmental Law and its struggle to gain acceptance and recognition. However, we are probably some way off the position suggested by de Ameida Silva in Brazil that Animal Law is so important that it should be compulsory for all law students. ${ }^{77}$ Few subjects in the socio-legal stable receive such positive endorsement.

The development of Animal Law would be very much in line with recent crossdisciplinary developments in the humanities that focus on the environmental or ethical dilemmas of our interaction with the natural world. Rose et al. suggest that this work is challenging traditional approaches to anthropology, philosophy, science, sociology and history amongst others. ${ }^{78}$ It would provide a new lens though which to view laws relating to animals for both academics and students and open up potential areas of research. It would enable the UK legal academy to take its place at the table and discuss how best to protect all species on the planet. It has the potential to do the same for legal education in the UK as has happened in the humanities and legal education in the US, by helping to open our eyes to the ecological imperatives of the twenty-first century.

The effect of studying Animal Law can be profound and transformative: 'I did religious education at school and it didn't make me religious. I did physical education and it didn't make me want to be a runner. But I've done Animal Law and it's changed my life. ${ }^{79}$ Perhaps we should offer this opportunity to more law students.

Open Access This article is distributed under the terms of the Creative Commons Attribution 4.0 International License (http://creativecommons.org/licenses/by/4.0/), which permits unrestricted use, distribution, and reproduction in any medium, provided you give appropriate credit to the original author(s) and the source, provide a link to the Creative Commons license, and indicate if changes were made.

\footnotetext{
77 T. de Almeida Silva, supra n. 11, p. 529.

78 D. Rose, T. van Dooren, M. Chrulew, S. Cooke, M. Kearnes and E. O”Gorman, "Thinking Through the Environment, Unsettling the Humanities" (2012) 1 Environmental Humanities 1.

79 Katy Makin, LLB Graduate of LJMU, 2013. Katy went on to do marine conservation work in Tanzania before commencing the UK Legal Practice Course.
} 